\title{
Hippocampal Changes in Developing Postnatal Mice following Intrauterine Exposure to Domoic Acid
}

\author{
K. Dakshinamurti, ${ }^{1}$ S. K. Sharma, ${ }^{1}$ M. Sundaram, ${ }^{2}$ and T. Watanabe ${ }^{1, a}$ \\ ${ }^{1}$ Department of Biochemistry and Molecular Biology and ${ }^{2}$ Department of Internal Medicine, University of Manitoba, \\ Winnipeg, Manitoba, Canada R3E OW3
}

\begin{abstract}
Domoic acid $(0.6 \mathrm{mg} / \mathrm{kg})$ was injected intravenously through the caudal vein in pregnant female mice on the 13 th day of gestation and EEG was monitored in the developing progeny during postnatal days $10-30$. No clinical seizure activity was observed during this period. However, these mice demonstrated generalized electrocortical inhibition associated with diffuse spike and wave activity in their basal EEG records. Intrauterine domoic acid-exposed (IUD) mice had significantly reduced seizure thresholds to an additional dose of domoic acid, given postnatally. At the light microscopic level, hippocampus of IUD mice exhibited age related developmental neurotoxicity. No cellular damage was observed on postnatal day 1 . On day 14 , severe neuronal damage was observed in the hippocampal CA3 and dentate gyrus regions. On day 30, in addition to CA3 and dentate gyrus, CA4 was also involved. Brain regional GABA levels were significantly reduced and glutamate levels increased in IUD mice. Kainate receptor binding to hippocampal synaptosomal membranes trom IUD mice at $30 \mathrm{~d}$ of age was significantly increased. There was also an enhanced ${ }^{45} \mathrm{Ca}$ influx into cortical and hippocampal slices of these mice. These findings suggest that intrauterine exposure to domoic acid can induce hippocampal excitotoxicity by increasing the neuronal calcium influx through kainate receptor activation. Histological changes suggest progressive hippocampal damage in IUD mice, but without overt clinical seizures.
\end{abstract}

[Key words: domoic acid, computerized EEG, kainate receptors, GABA, glutamate, hippocampal morphology]

Domoic acid (a neurotoxin isolated from contaminated mussels), like kainic acid and acromelic acid, is a rigid structural analog of glutamate. Interest in domoic acid has increased due to health hazards associated with the accidental ingestion of this compound (Teitelbaum et al., 1990). Excitotoxicity of domoic acid appears to be the result of kainate receptor activation (Debonell et al., 1989). Kainate receptor density in the rat hippocampus is very high compared to other brain regions (Foster ct al., 1981). Previous studies by Schwob et al. (1980) have re-

Received Dec. 7, 1992; revised Apr. 22, 1993; accepted May 3, 1993.

This work was supported by a grant from the Medical Research Council of Canada and the Health Sciences Center, Winnipeg, Canada. T.W. was an MRC Visiting Scientist.

Correspondence should he addressed to Dr. K. Dakshinamurti, Department of Biochemistry and Molecular Biology, Faculty of Medicine, University of Manitoba, Winnipeg, Manitoba, Canada R3E OW3.

aresent address: Department of Hygiene and Preventive Medicine, Yamagata University School of Medicine, Yamagata 99023, Japan.

Copyright (C) 1993 Society for Neuroscience $0270-6474 / 93 / 134486-10 \$ 05.00 / 0$ ported that systemic injection of kainic acid produces wide spread structural and functional lesions in the rat brain. Domoic acid also produces structural and functional lesions in the CA1, CA3, and the dentate gyrus of hippocampus (Stewart et al., 1990; Strain and Tasker, 1991). Recently, we showed that domoic acid is 25 times more potent than kainic acid in inducing excitotoxic effects on hippocampal CA3 neurons (Dakshinamurti et al., 1991). Domoic acid enhances $\mathrm{K}^{+}$-induced glutamate release from hippocampal slices, inhibits glutamic acid decarboxylase (GAD) activity, reduces brain regional GABA, and increases neuronal glutamate levels of normal adult rat brain (Dakshinamurti et al., 1991).

Although various chemicals including kainic acid (Ben-Ari, 1985) have been used in the kindling models of epilepsy, there is no information on the effects of intrauterine exposure to neurotoxins on the progeny. In this study we investigated the effects on the progeny of a subconvulsive dose of domoic acid given during midgestation. The following investigations were made on the offspring (IUD) obtained from the domoic acid-injected dams: (1) routine and quantitative EEG analysis, (2) determination of seizure thresholds for a second (postnatal) exposure to domoic acid, and (3) neuromorphological and (4) neurochemical analyses.

\section{Materials and Methods}

Nulliparous CD-1 mice (8-10 weeks, weighing 25-30 gm) of either sex were purchased from Charles River Breeding Farms (Quebec, Canada). Urethane, muscimol, GABA, and glutamate were purchased from Research Biochemicals (Natick, MA). All other chemicals used were of reagent grade and purchased from Sigma Chemical Co. (St. Louis, MO).

Breeding. All animals had free access to laboratory chow and water. They were kept at $23^{\circ} \mathrm{C}$ and relative humidity of $60 \%$ in the Central Animal Facility $(10 \mathrm{hr}$ in dark and $14 \mathrm{hr}$ in the light). Three female mice (weighing $30 \pm 2.5 \mathrm{gm}$ ) were housed in breeding cages with one male (weighing $35 \pm 2 \mathrm{gm}$ ). Every day female mice were checked for sperm positivity from their vaginal swabs. Sperm-positive females (day 0 of gestation) were kept in individual cages. Domoic acid dissolved in phosphate-buffered saline ( $\mathrm{pH} 7.3$ ) was injected to the dams by the tail vein on the 13th day of gestation, the time of maximal hippocampal cell proliferation (Angevine, 1965). Various doses of domoic acid were injected in pilot experiments to assess the level of toxicity. At the highest dose of domoic acid tested $(2.4 \mathrm{mg} / \mathrm{kg}$ body weight, i.v.) all pregnant females developed severe tonic-clonic convulsions within $15 \mathrm{~min}$ of injection and died within $2.5-3 \mathrm{hr}$ in status epilepticus. Lower doses had progressively less severe effects. We decided to use a subconvulsive dose of domoic acid, which was one-fourth of the convulsive dose. Five pregnant mice were injected with domoic acid $(0.6 \mathrm{mg} / \mathrm{kg}$, i.v) through the caudal vein. Five other pregnant mice of the same gestational age, injected with the vehicle (phosphate-buffered saline, $\mathrm{pH}$ 7.3) served as controls. The progeny of hoth control and experimental groups were examined on postnatal days 10,20 , and 30 for the residual effects of intrauterine domoic acid exposure. Gestation and lactation appeared to 
be normal in dams given domoic acid. No overt symptoms of seizure activity were observed in dams or the progeny. These animals appeared physically normal, without significant differences in body or brain weights between control and IUD mice.

$E E G$ recordings. Five mice from each of the control and intrauterine domoic acid-exposed (IUD) groups at 10, 20, and $30 \mathrm{~d}$ of age, respectively, were anesthetized with intraperitoneal urethane $(1.8 \mathrm{mg} / \mathrm{gm}$ body weight). Pin-type silver-silver chloride electrodes were placed over the frontal and occipital regions of the skull on both cerebral hemispheres using coordinates described by Gourmelon et al. (1986). Bipolar electroencephalogram (EEG) was recorded from the anteroposterior and transverse montage by using a set of four electrodes $\left(\mathrm{F}_{3}-\mathrm{F}_{4}, \mathrm{O}_{1}-\mathrm{O}_{2}\right)$, each connected to a common average reference. On-line spectral analysis of the four leads of EEG was done using STELLATE RHYTHM PROGRAM (version 6.0, Stellate Systems, Westmount, Canada), using a Commodore PC-40-III computer and Nihon Kodon EEG machine (Nihon Kodon America, Inc., Mississauga, Canada) as described by Sharma and Dakshinamurti (1992). Data were stored using biological banker and videocassette recorder for the analysis of frequency and power spectra. EEG was digitized at a sampling rate of $32 \mathrm{~Hz}$ with 10 bit analog-todigital conversion resolution using a $0.1 \mathrm{~Hz}$ low-pass filter fast Fouriertransformed in sweeps of $5.12 \mathrm{sec}$ and seven sweeps added per block. Frequency bands of delta $(0.5-4.5 \mathrm{~Hz})$, theta $(4.5-8 \mathrm{~Hz})$, alpha $(8-13.5$ $\mathrm{Hz}$ ), and beta $(13.5-32 \mathrm{~Hz})$ were quantitated for dominant frequency in each band and absolute power in picowatts. EEG data were printed out simultaneously on a teletype model 43 printer and compressed spectral array (CSAs) were plotted on a Hewlett-Packard $x-y$ plotter (Mississauga, Canada).

EEG recordings were also made after injecting a postnatal dose of domoic acid $(0.6 \mathrm{mg} / \mathrm{kg})$ through the tail vein to both IUD and control mice. Control mice were pups of dams injected intravenously with the vehicle saline in midgestation. Seizure latencies (time in seconds, at which typical spiking was observed in the basal EEG records) and duration $(\mathrm{sec})$ of ictal and interictal spikes (sec) were compared between control and IUD mice at postnatal days 10,20 , and 30. Frequency and power spectral changes were also analyzed after muscimol $\left(\mathrm{GABA}_{\mathrm{A}}\right.$ agonist) $(0.6 \mathrm{mg} / \mathrm{kg})$ intravenous injection in both control and IUD mice. EEG of 30-d-old animals was also recorded from the left and right hippocampus regions using stereotaxic coordinates $(2 \mathrm{~mm}$ frontal to lambda, $2 \mathrm{~mm}$ lateral to midline, and $1.8 \mathrm{~mm}$ below the skull surface). Whishaw's (1977) equation was applied to determine the exact stereotaxic coordinates. Animals were killed by an overdose of urethane, and brains were removed. The position of the hippocampal electrodes was verified by fixing the tissues in $10 \%$ buffered formalin and preparing $5-\mu \mathrm{m}$-thick hematoxylin and eosin-stained transverse sections.

Statistical analysis of the EEG data was carried out using NUMBER CRUNCHER statistical software (version 5.0) and repeated measures twoway analysis of variance (ANOVA) followed by Newman-Keuls test.

Neuromorphological studies. For studying the residual effects of intrauterine exposure to domoic acid on developing postnatal mice, five pups each from control and IUD groups were used at the following chronological ages, respectively: day 1 , day 14 , and day 30 . These animals were anaesthetized with diethyl ether and perfused transcardially through the left ventricle with $2.5 \%$ buffered glutaraldehyde for $10 \mathrm{~min}$, and their brains were fixed in $10 \%$ buffered formalin ( $\mathrm{pH} \mathrm{7.4)}$ for 1 week. Tissues were dehydrated with different grades of ethanol. Paraffinembedded sections of $5 \mu \mathrm{m}$ were stained with DNA stain (thionincpyronine-G) to localize histological damage.

Neurochemical studies. Neurochemical analyses were done in companion experiments using another set of experimental and control mice. In the first experiment brain regional $\gamma$-aminobutyric acid (GABA) and glutamate levels were measured. Five IUD and five control mice were used at postnatal day 30 . Both GABA and glutamate levels of the frontal cortex and the hippocampi were measured. In the second experiment five normal mice at age of $30 \mathrm{~d}$ were administered domoic acid $(0.6$ $\mathrm{mg} / \mathrm{kg}$ through the caudal vein) and another five mice of similar age were injected with saline. They were decapitated after $4 \mathrm{hr}$. The brains were removed, and the frontal cortex and hippocampus were isolated and stored at $-70^{\circ} \mathrm{C}$ for the assay of glutamine synthetase (GS), glutamic acid decarboxylase (GAD), and amino acid neurotransmitters. This study was performed to assess the short-term effect of domoic acid on brain regional GS and GAD activities.

Neurotransmitter analysis. The tissues were weighed over dry ice and homogenized in $0.1 \mathrm{~m}$ ice-cold perchloric acid. The supernatants $(15,000$ $\times g, 20 \mathrm{~min}$ ) were filtered (Conz; syringe tip filters, $0.2 \mu \mathrm{m}$ ) for the determination of GABA and glutamate by high-performance liquid chromatography (HPLC) with electrochemical detection as described by Donazati and Yamamoto (1988).

GS activity. GS activity was medsured essentially as described by Pishak and Phillips (1979) and modified by Patel et al. (1982). Briefly, mice were killed by cervical dislocation and brain tissues were immediately removed and washed in cold imidazol-buffered saline $(25 \mathrm{mM}$ imidazol- $\mathrm{HCl}$, pH 7.2, $5.4 \mathrm{~mm} \mathrm{KCl,} 137 \mathrm{~mm} \mathrm{NaCl}$, and $5.5 \mathrm{~mm}$ glucose). Tissues were blotted and minced in $10 \mathrm{~mm}$ imidazol- $\mathrm{HCl}$ buffer $(\mathrm{pH}$ 6.8) containing $0.5 \mathrm{~mm}$ EDTA (disodium salt), homogenized at $4^{\circ} \mathrm{C}$, and sonicated at $300 \mathrm{~W}$ for $15 \mathrm{sec}$. Homogenates $(10 \% \mathrm{w} / \mathrm{v})$ were centrifuged at $27,000 \times g$ for $1 \mathrm{hr}$ at $4^{\circ} \mathrm{C}$. The supernatant fractions were used for enzyme assays. The assay mixtures contained the following components in a final volume of $50 \mu \mathrm{l}: 50 \mathrm{~mm}$ imidazol $\mathrm{HCl} \mathrm{pH} \mathrm{6.8,}$ $15 \mathrm{mM} \mathrm{MgCl}_{2}, 10 \mathrm{~mm} \mathrm{ATP}, 10 \mathrm{~mm} \mathrm{~L}-\mathrm{U}-{ }^{14} \mathrm{C}$-glutamate $(0.8 \mathrm{mCi} / \mathrm{mmol})$, $4 \mathrm{mM} \mathrm{NH}_{4} \mathrm{Cl}, 1 \mathrm{mM} 2$-mercaptoethanol, and the enzyme sample. All incubations were carried out at $37^{\circ} \mathrm{C}$ for $30 \mathrm{~min}$. The reaction was stopped by adding 1 mil of ice-cold distilled water and placing the tubes immediately on ice for a period not exceeding $15 \mathrm{~min}$. Glutamine was isolated from the medium by using a Dowex- 1 acetate column $(0.7 \times$ $3 \mathrm{~cm}$ ), and the column was washed with $5 \mathrm{ml}$ of distilled water; $6 \mathrm{ml}$ fractions were collected, and the radioactivity of the fractions was determined in a Beckman beta scintillation counter using $5 \mathrm{ml}$ of ScintiVerse as a cocktail. Protein concentration of the supernatants used for GS estimation was determined by using Bio-Rad dye (Bradford, 1976). GS activity was expressed as glutamine synthesized $/ \mathrm{mg}$ protein $/ \mathrm{hr}$.

$G A D$ activity. GAD activity was measured as described previously by Dakshinamurti and Stephens (1969). GAD, in the presence of the coenzyme pyridoxal phosphate (PLP), decarboxylates $1-{ }^{14} \mathrm{C}$-glutamic acid to yield ${ }^{14} \mathrm{CO}_{2}$. The incubation medium (final vol, $1.15 \mathrm{ml}$ ) contained $115 \mu \mathrm{mol}$ of potassium phosphate buffer ( $\mathrm{pH} 6.5$ ), and graded amounts of the brain homogenate. The reaction was started by the addition of $20 \mu \mathrm{mol}$ of $\mathrm{L}^{-14} \mathrm{C}$-glutamic acid $(4 \mu \mathrm{Ci} / \mathrm{mmol})$. GAD of brain homogenates was assayed in the presence of excess $(0.1 \mu \mathrm{mol})$ PLP added in vitro. Triton X-100 $(0.25 \% \mathrm{w} / \mathrm{v})$ was added to the homogenization medium ( $0.25 \mathrm{M}$ sucrose) to ensure maximal liberation of the enzyme from the tissue. Incubation was carried out at $37^{\circ} \mathrm{C}$ for $60 \mathrm{~min}$. The reaction was stopped by adding $50 \mu \mathrm{l}$ of $5 N$ sulfuric acid. The above reaction mixture was again incubated for another $90 \mathrm{~min}$ to trap the evolved ${ }^{14} \mathrm{CO}_{2}$ on hyamine hydroxide $(50 \mu \mathrm{l})$ impregnated Whatman no. $1(4 \mathrm{~mm} \times 15 \mathrm{~mm})$ filter paper that was kept in the inner vial during the entire incubation period. Filter paper with trapped ${ }^{14} \mathrm{CO}_{2}$ was transferred to a scintillation vial, $5 \mathrm{ml}$ of ScintiVerse cocktail was added, and the radioactivity was determined in a Beckman beta scintillation counter. The GAD enzymatic activity was expressed as GABA synthesized/ $\mathrm{mg}$ protein $/ \mathrm{hr}$.

Kainate receptor binding. Kainate receptor binding kinetics were determined using the method described by London and Coyle (1979). Briefly, hippocampal tissue was homogenized in 20 vol of ice cold 0.32 M sucrose. The homogenate was centrifuged at $1000 \times g$ for $10 \mathrm{~min}$, and the pellet containing crude nuclear fraction was discarded. Supernatant was centrifuged at $17,000 \times g$ for $20 \mathrm{~min}$. The pellet was suspended in ice-cold distilled water, disrupted with polytron PT-10, and centrifuged at $8000 \times g$ for $20 \mathrm{~min}$. The soft upper layer of the pellet and supernatant were collected and centrifuged again at $48,000 \times g$ for 20 min to obtain the crude synaptosomal membranes. The pellet was either stored at $-70^{\circ} \mathrm{C}$ before use or resuspended in distilled water and centrifuged again at $48,000 \times g$ for $20 \mathrm{~min}$. The washed pellet was suspended in $0.05 \mathrm{~m}$ Tris citrate buffer $\mathrm{pH} 7.1$ at $4^{\circ} \mathrm{C}$. Aliquots of crude synaptosomal membranes ( $500 \mu \mathrm{g}$ of protein per tube) were incubated in triplicate at $4^{\circ} \mathrm{C}$ for $20 \mathrm{~min}$ in $1 \mathrm{ml}$ of $0.05 \mathrm{M}$ Tris-citrate buffer (pH 7.1 at $4^{\circ} \mathrm{C}$ ) in $5 \mathrm{ml}$ tubes containing varying concentrations $(10-600$ $\mathrm{nM})$ of ${ }^{3} \mathrm{H}$-kainate with or without cold kainate $(10 \mu \mathrm{M})$. After incubation the samples were filtered through GF/B filters using a Brandel Cell Harvester. Three washings of $5 \mathrm{ml}(0.05 \mathrm{~m}$ Tris-citrate buffer, $\mathrm{pH} 7.1)$ each were made to remove unbound radioactivity. Bound radioactivity was determined using a Beckman beta scintillation counter by transferring the filter paper to a scintillation vial with $5 \mathrm{ml}$ of the scintillant (Scintiverse). Specific ${ }^{3} \mathrm{H}$-kainate binding was obtained by subtracting total binding from nonspecific binding in presence of $10 \mu \mathrm{M}$ cold kainate. Protein concentration was measured with Bio-Rad dye (Bradford, 1976), using bovine serum albumin as the standard. Specific binding data were analyzed according to Scatchard (1949) using equilibrium binding data analysis software, from which the binding parameters, maximal binding $\left(B_{\max }\right)$, and dissociation constant $\left(K_{d}\right)$ were determined. 


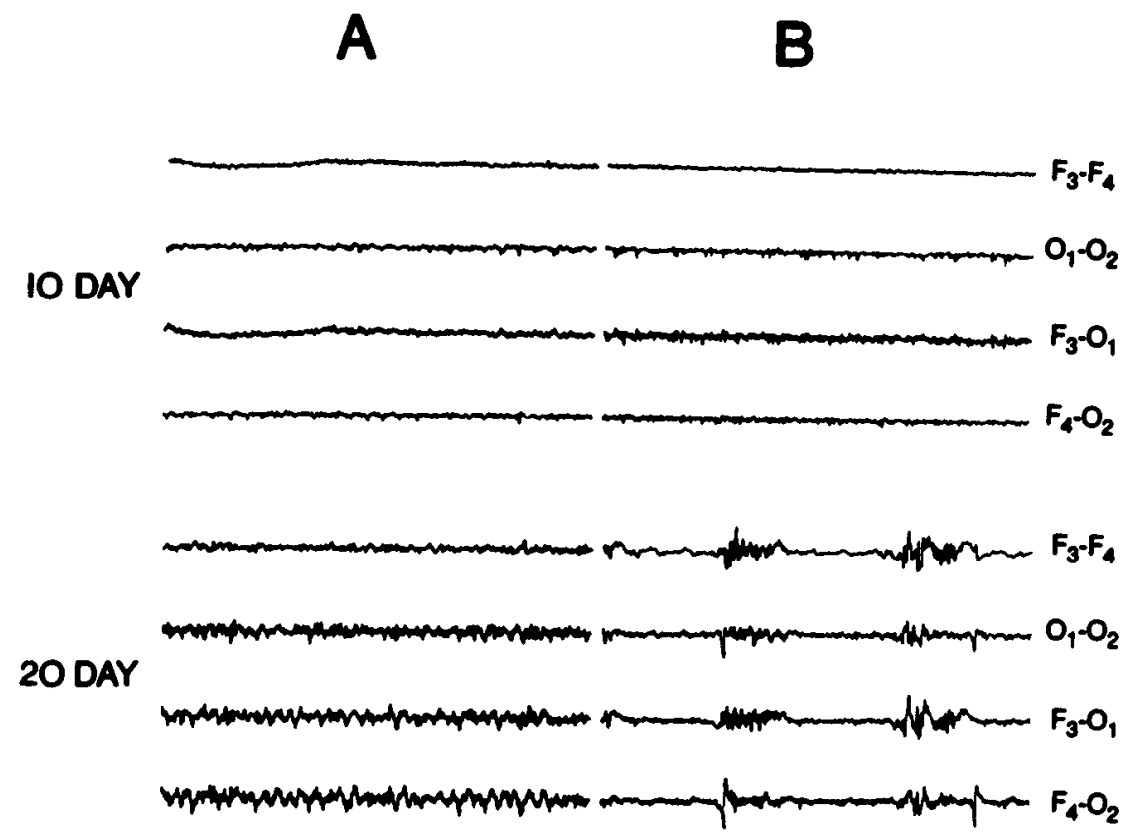

Figure 1. A, EEG records of 10-30-dold control mouse pups, representing high-frequency low-amplitude record. $B$, EEG of 10-30-d-old pups of dams that received $0.6 \mathrm{mg} / \mathrm{kg}$ domoic acid intravenously during 13 th day of gestation (IUD), representing high-amplitude, reduced background frequency and with frequent burst discharge activity.
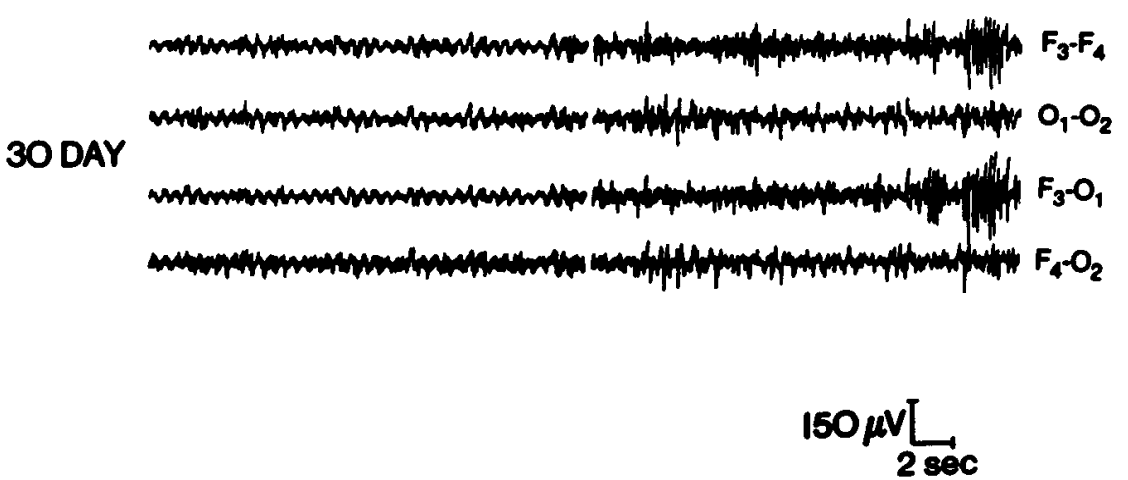

${ }^{45} \mathrm{Ca}$ influx through cortical and hippocampal slices. Calcium influx through cortical and hippocampal slices was studied in both acute and long-term experiments. In the acute experiment 30-d-old mice were injectcd intravenously with domoic acid $(0.6 \mathrm{mg} / \mathrm{kg})$, animals were killed after $4 \mathrm{hr}$, and calcium influx in cortical and hippocampal slices was determined. In the long-term experiments 30 -d-old IUD mice were used for measuring calcium influx into these brain tissues to determine the effect of intrauterine domoic acid exposure.

Calcium influx was determined as described earlier by Viswanathan et al. (1990). Briefly, after decapitation, the cerebral cortex and hippocampal regions of mice under study were isolated. Transverse cortical or hippocampal slices $(300-400 \mu \mathrm{m})$ were prepared using Mcllwain tissue chopper. The slices were then equilibrated in Krebs' Henseleit medium (composition in mmol/liter: $\mathrm{NaCl}, 118 ; \mathrm{KCl}, 4.7 ; \mathrm{KH}_{2} \mathrm{PO}_{4}$, $1.4 ; \mathrm{NaHCO}_{3}, 25 ; \mathrm{MgSO}_{4}, 1.2 ; \mathrm{CaCl}_{2}, 2.5 ;$ glucose, 11) pH 7.4 at $37^{\circ} \mathrm{C}$, aerated with $95 \% \mathrm{O}_{2}, 5 \% \mathrm{CO}_{2}$ for the first $60 \mathrm{~min}$. The slices were incubated for the next $45 \mathrm{~min}$ in the same medium containing $5 \mu \mathrm{Ci}$ / $\mathrm{ml}$ of ${ }^{45} \mathrm{Ca}$. At the end of the incubation period the slices were plunged into ice-cold lanthanum chloride solution (in mmol/liter: $\mathrm{NaCl}, 132$; $\mathrm{KCl}, 5.9 ; \mathrm{MgCl}_{2}, 1.25 ; \mathrm{LaCl}_{3}, 50$; glucose, 11 ; Tris maleate, 15) pH 6.8 to block voltage-operated calcium channel activity. After $30 \mathrm{~min}$ in lanthanum chloride solution, the slices were blotted between the folds of Whatman no. 4 filter paper. The slices were then digested for $18 \mathrm{hr}$ in $100 \mu$ lof concentrated perchloric acid-nitric acid solution $(1: 1)$. The scintillant (Scintiverse) was added to the digest, and radioactivity was determined using a Beckman beta scintillation counter. Calcium influx was expressed using the formula

${ }^{45} \mathrm{Ca}$ influx $(\mathrm{mmol} / \mathrm{kg}$ wet weight $/ \mathrm{hr})=($ disintegrations per $\mathrm{min}$ in tissue $/$ wet weight in $\mathrm{kg} \times \mathrm{mmol}$ of $\mathrm{Ca} /$ liter of medium/disintegrations/min/ liter of medium).

\section{Results}

Pregnant dams treated with the highest dose of domoic acid $(2.4 \mathrm{mg} / \mathrm{kg}$ body weight intravenously on the 13 th day of gestation) exhibited immobilization and rearing within $5 \pm 2 \mathrm{~min}$ followed by stiffening and tail vibrations within $7.5 \pm 1.5 \mathrm{~min}$. Movement of forepaws started after $10 \pm 2 \mathrm{~min}$, and generalized tonic-clonic movements with jaw opening reflex and hypersalivation were observed in $15 \pm 3 \mathrm{~min}$. These animals exhibited whole-body tremors in the next $25 \pm 4 \mathrm{~min}$. This typc of scvere convulsive activity persisted during the next $2.5 \pm 0.5 \mathrm{hr}$, and the animals died at $4.2 \pm 0.4 \mathrm{hr}$. Lower doses of domoic acid led to progressively less severe seizures. Dams treated with 0.6 $\mathrm{mg}$ domoic acid $/ \mathrm{kg}$ body weight on the 13 th day of gestation exhibited slight hypoactivity within $15 \mathrm{~min}$ of injection. This was followed by immobilization, which persisted for the next $30 \mathrm{~min}$. No overt symptoms of domoic acid neurotoxicity such as clinical seizures and behavioral abnormalities were noticed in the dams during gestation and lactation. In all our experiments we used this dose of domoic acid.

Offspring of dams exposed to domoic acid $(0.6 \mathrm{mg} / \mathrm{kg}$ body weight) during gestation (IUD) externally appeared normal. There was no significant difference between the body weights of pups from the control and IUD groups $(1.43 \pm 0.05 \mathrm{gm}$ and $1.50 \pm$ $0.03 \mathrm{gm}$ for control and experimental groups, respectively, at 


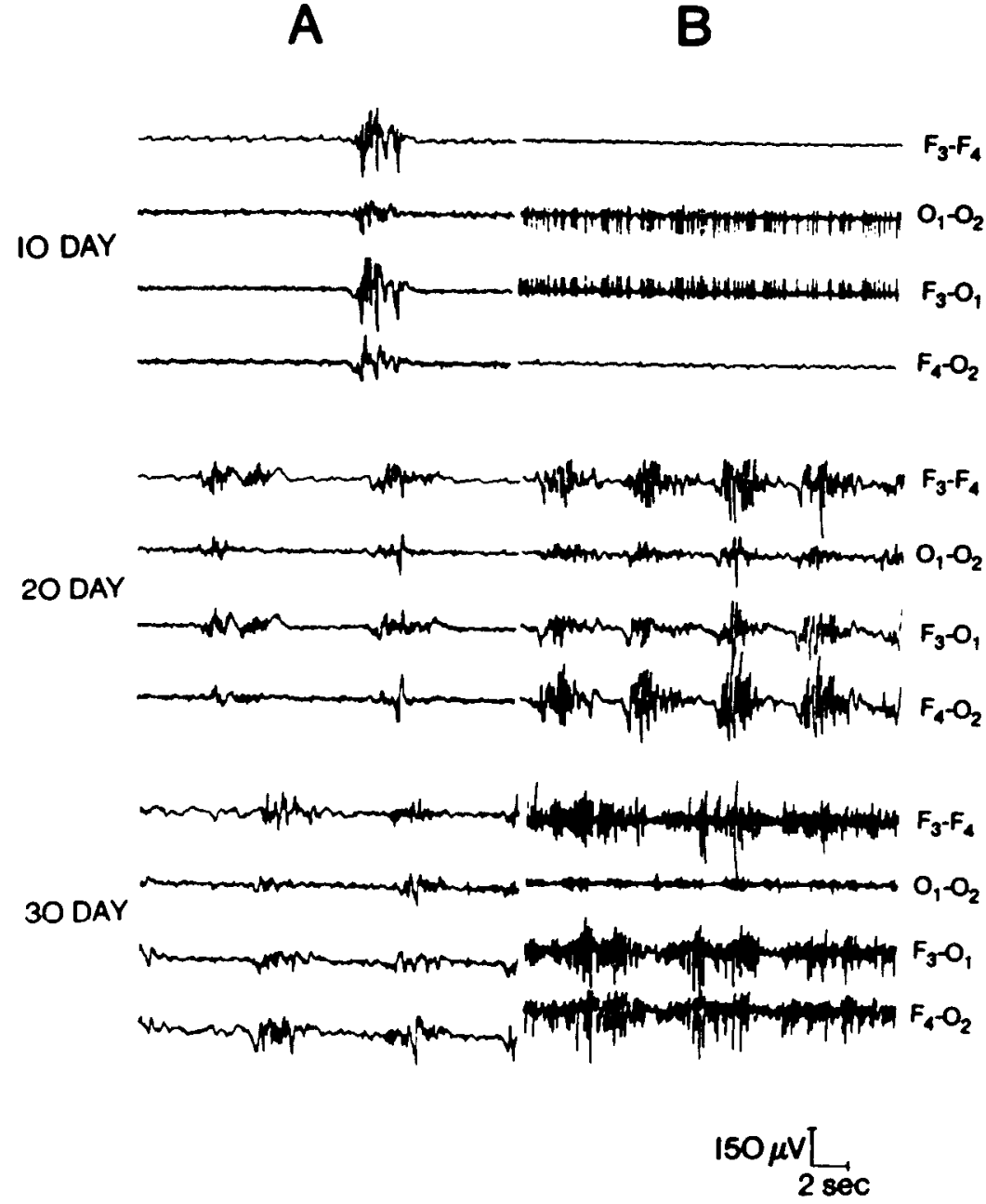

Figure 2. A, EEG records, representing a typical electrocortical inhibition on day 10 , occasional spike activity on day 20 , and burst discharge activity on day 30 in control mice in response to domoic acid $(0.6 \mathrm{mg} / \mathrm{kg}$, i.v.). $B$, IUD mice exhibiting complete electrocortical inhibition and continuous spike activity on day 10 , occasional spike and burst activity on day 20 , and continuous burst discharge activity on day 30 in response to a second exposure to domoic acid. birth). There was no difference in the brain weights between the two groups. The litter size was similar in both the groups. Control dams delivered $14 \pm 3$ pups, whereas domoic acid-treated dams delivered $15 \pm 4$ pups. Brain and hippocampal formation of the two groups did not exhibit any macroscopic differences.

\section{Basal EEG records}

No overt clinical seizure activity was observed in the IUD mice at any time postnatally. However, spike activity was secn in the basal EEG records of these animals at postnatal day 10. Increasing abnormalities in the EEG records of IIJD mice were observed at 20 and $30 \mathrm{~d}$ of chronological age. IUD mice exhibited increased amplitude and low background frequencies as compared to control mice at corresponding ages of 10,20 , and $30 \mathrm{~d}$, respectively. EEG records of the IUD mice were characterized by a typical reduction in the background frequency compared to control animals (Fig. 1). Ten-day-old pups exhibited minimal EEG changes, characterized by generalized electrocortical inhibition and minor spike activity. On day 20, EEG background frequency was increased in both control and IUD mice. However, IUD mice exhibited typical spike and wave activity in their basal records. At 30 d of age EEG spike activity of IUD mice was transformed into frequent burst discharge activity.

\section{Effect of postnatal exposure to domoic acid}

Control mice of age $10 \mathrm{~d}$ that had only the postnatal administration of domoic acid exhibited occasional spiking after domoic acid injection (Fig. 2). In the IUD pups of age $10 \mathrm{~d}$, a complete inhibition of EEG background frequency and continuous spike activity were noticed after $5 \pm 2$ min of intravenous domoic acid injection. Control mice of age $20 \mathrm{~d}$ exhibited intermittent spike activity buried in the high-frequency EEG record, whereas IUD mice exhibited frequent burst discharges in their EEG records. Control mice of age $30 \mathrm{~d}$ showed occasional spiking with a few bursts, whereas IUD mice exhibited continuous burst discharge activity. Upon muscimol $(0.6 \mathrm{mg} / \mathrm{kg})$ injection into the caudal vein, IUD-exposed mice exhibited an EEG similar to that of controls within $15 \pm 3 \mathrm{~min}$.

\section{Seizure thresholds}

IUD-exposed mice had significantly reduced seizure thresholds for a second exposure to domoic acid $(0.6 \mathrm{mg} / \mathrm{kg}, \mathrm{i} . \mathrm{v}$.) at 10 , 20 , or $30 \mathrm{~d}$ of age. Animals between 7 and $10 \mathrm{~d}$ of age were highly susceptible to a second exposure to domoic acid. Seizure activity in these animals was represented by generalized tonicclonic motor activity of 2.5-3 hr duration. Generalized tonicclonic convulsions were followed by $30-45 \mathrm{~min}$ of catatonia characterized by rearing and immobilization. Soon after recov- 
Figure 3. Reduced seizure thresholds to domoic acid $(0.6 \mathrm{mg} / \mathrm{kg}$, i.v.) were represented by significantly increased EEG burst duration $(p<0.01)$, burst tudes $(p<0.01)$ in IUD, as compared frequency $(p<0.05)$, and burst amplito control, 30-d-old mice.
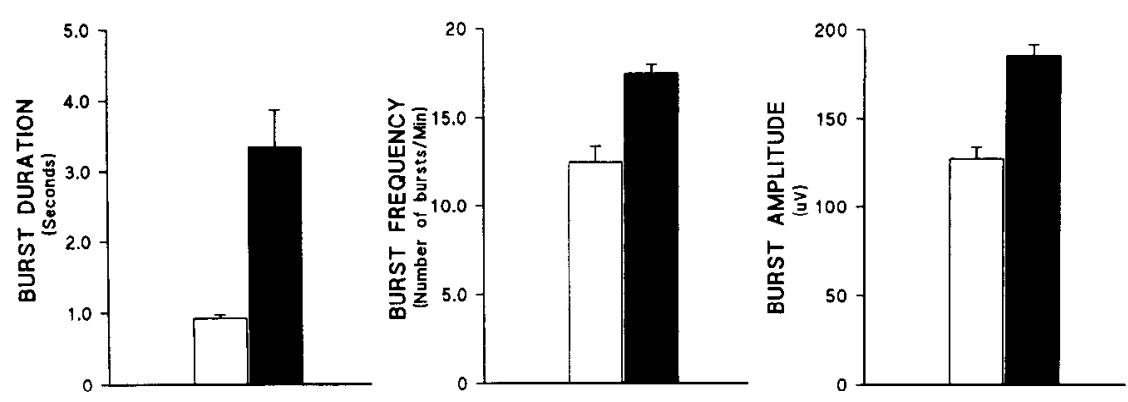

ery from generalized seizure activity, these animals appeared weak and less active for about $30-45 \mathrm{~min}$. After this duration the animals appeared like controls. Ten- to fifteen-day-old IUD mice died in status epilepticus within 3-4 hr of a second exposure to domoic acid, whereas control mice recovered after $2.5 \pm 0.2 \mathrm{hr}$ of generalized seizure activity. Seizure activity in 30-d-old IUD mice was associated with tail vibrations, body tremors, and generalized tonic-clonic movements of hind and forepaws, observed within $7.5 \pm 2.0 \mathrm{~min}$ as compared to $20 \pm$ $5 \mathrm{~min}$ in the control mice. As the age advanced from postnatal day 10 to 30 , the seizure thresholds were increased in control and reduced in IUD mice. With a second injection of domoic acid $(0.6 \mathrm{mg} / \mathrm{kg}$, i.v. $)$, IUD mice reached grade IV type seizure activity (characterized by continuous EEG burst discharges), whereas control mice had only grade I-III type seizure activity (characterized by generalized electrocortical inhibition followed by occasional spike and wave activity).

Significantly reduced seizure thresholds to a second exposure of domoic acid were also evident from measurements of seizure latencies (time in minutes at which a typical spike and wave activity were observed) and ictal and interictal spike duration (seconds) as compared to buffered saline-injected controls. Seizure latencies were $7.5 \pm 1.5 \mathrm{~min}$ and $15.0 \pm 2.3 \mathrm{~min}(p<$ $0.01)$, respectively, in control and IUD mice. Interictal spike duration was $35 \pm 4 \mathrm{sec}$ in IUD versus $20 \pm 3 \mathrm{sec}(p<0.05)$ in control mice. Ictal spike durations were $45 \pm 5 \mathrm{sec}$ in IUD as compared to $30 \pm 3 \sec (p<0.05)$ in control mice. EEG burst amplitude, burst frequency, and burst duration were also significantly increased in IUD mice upon a second exposure to domoic acid (Fig. 3).

\section{Hippocampal EEG}

EEG from hippocampal CA3 region was compared between control and IUD mice at age of $30 \mathrm{~d}$ to assess the residual effects of intrauterine domoic acid exposure. IUD mice exhibited intermittent burst discharge activity for $2.5 \pm 0.2$ sec intermixed with the background EEG frequency, while control mice did not exhibit any burst discharge activity. The EEG of hippocampal CA3 region also exhibited typical electrocortical inhibition in IUD mice (Fig. 4).

\section{Computerized EEG analysis}

To quantitate differences in the EEG power and frequency spectra between control and IUD mice, computerized EEG analysis was done. Relative dominance of delta and theta and reductions in alpha and beta powers were observed in the basal CSAs of IUD as compared to control mice on postnatal day 30 (Fig. 5). Delta and theta powers were further accentuated within $10.0 \pm$ $2.5 \mathrm{~min}$ by a second (postnatal) injection of domoic acid ( 0.6 $\mathrm{mg} / \mathrm{kg}$, i.v.) in these animals. Similar increases in delta and theta

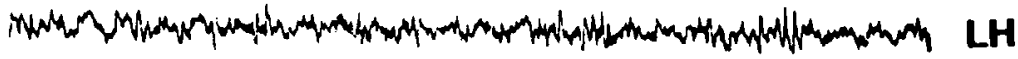

A
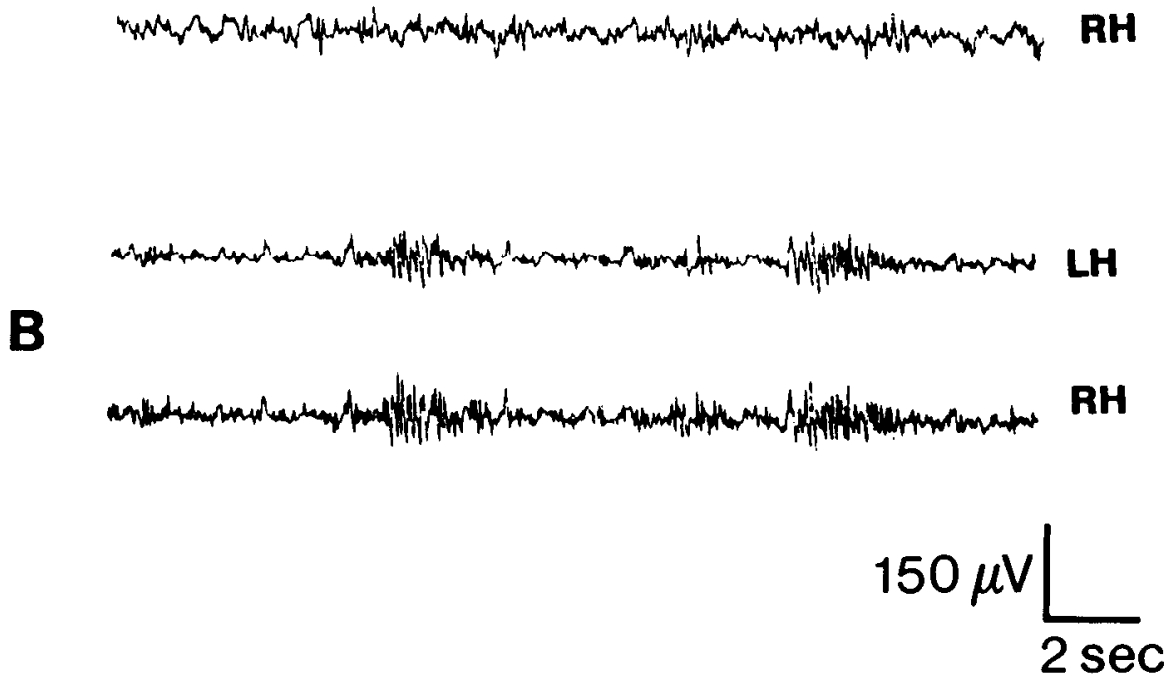

Figure 4. Basal EEG recording, obtained from left $(L H)$ and right $(R H)$ hippocampal CA 3 regions of control and IUD 30-d-old mice, exhibited reduced background frequency and frequent burst discharge activity in the EEG from hippocampal CA3 region. 

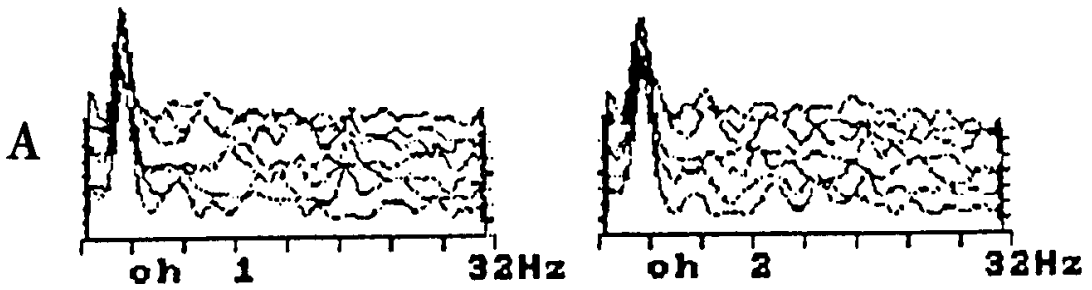

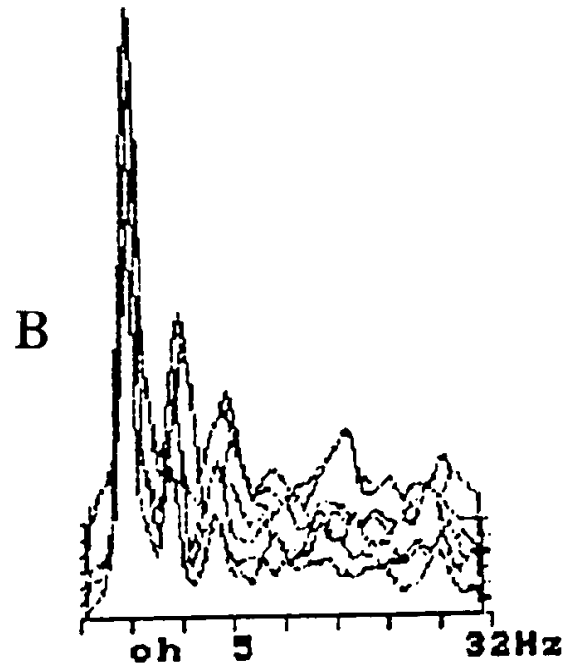

LH

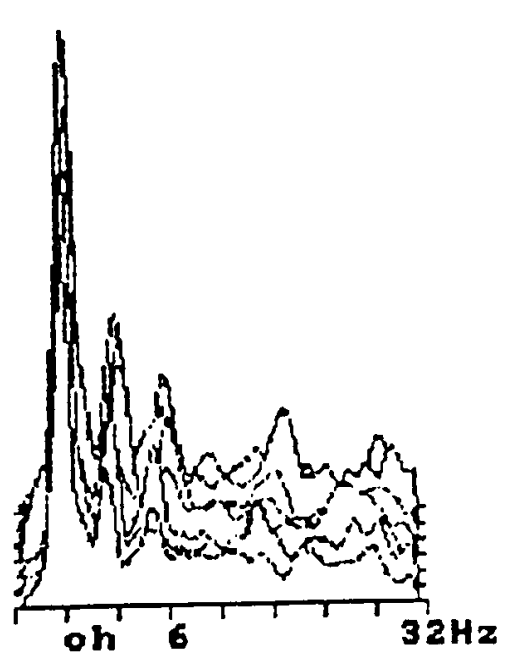

RH powers were observed in control mice after injection of domoic acid $(0.6 \mathrm{mg} / \mathrm{kg})$ through the caudal vein. However, the increase in the relative powers of delta and theta and reductions in alpha and beta activities in controls were not as prominent as those observed in IUD mice. The absolute powers of delta and theta rhythms were also significantly increased in both control and IUD mice in response to postnatal domoic acid (Fig. 6). No definite trend in the absolute powers of alpha and beta activities was observed in both controls and IUD mice. The EEG and CSAs were normalized, delta and theta powers reduced and alpha and beta increased following muscimol $(0.8 \mathrm{mg} / \mathrm{kg}$, i.v $)$ after $25 \pm 5 \mathrm{~min}$ and $40 \pm 5 \mathrm{~min}$, respectively, in control and IUD mice. Normal CSA patterns were restored after a lag of $12.5 \pm 3.0 \mathrm{~min}$ in IUD mice as compared to $7.5 \pm 3.0 \mathrm{~min}$ in control mice. Hippocampal EEG abnormalities were also evident from coherence and fast Fourier-transformed amplitude analyses.

\section{Morphological changes}

IUD mice exhibited an age-related selective neuronal damage in different hippocampal layers. At a chronological age of $1 \mathrm{~d}$, different hippocampal layers are not well differentiated. Therefore, no obvious symptoms of neuronal damage were observed at this stage. At the chronological age of $14 \mathrm{~d}$ neuropathological changes, characterized by densely stained, swollen, distorted

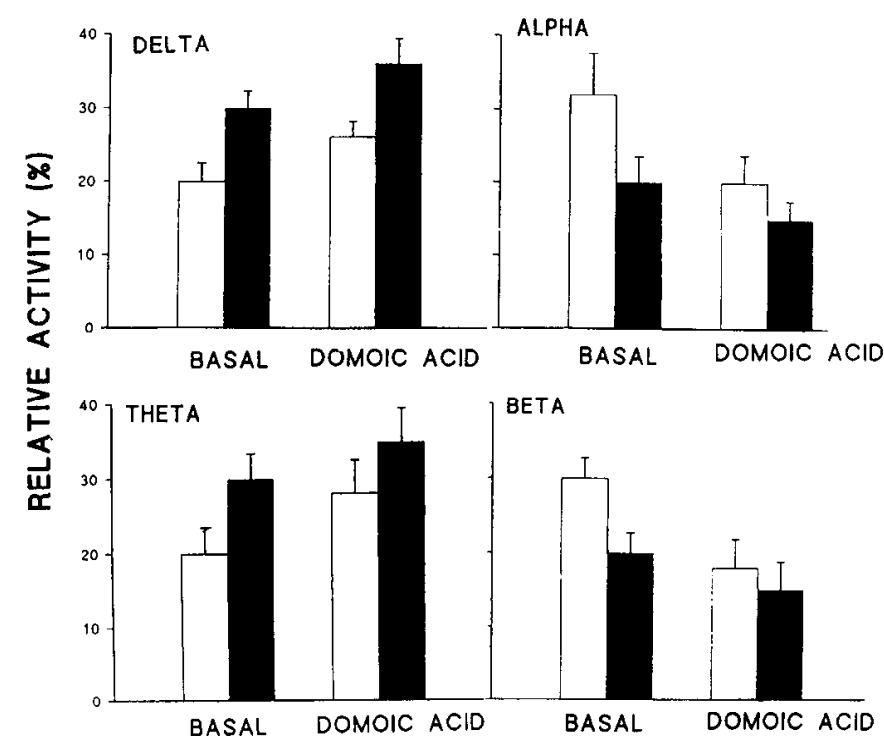

Figure 6. Quantitative analysis of various EEG frequency bands from control and IUD mice. $B A S A L$, Relative activities of delta and theta were significantly $(p<0.05)$ increased and those of alpha and beta reduced $(p<0.05)$ in IUD as compared to control mice. DOMOIC $A C I D$, Postnatal domoic acid treatment increased delta and theta and reduced alpha and beta activities in both control and IUD mice with still significant differences between these groups $(p<0.01)$.
Figure 5. Basal CSA of control left $(L H)$ and right $(R H)$ hippocampal CA3 regions of control and IUD 30-d-old mice. IUD mice exhibited relative dominance of delta and theta and reductions in alpha and beta activities in their basal records. 

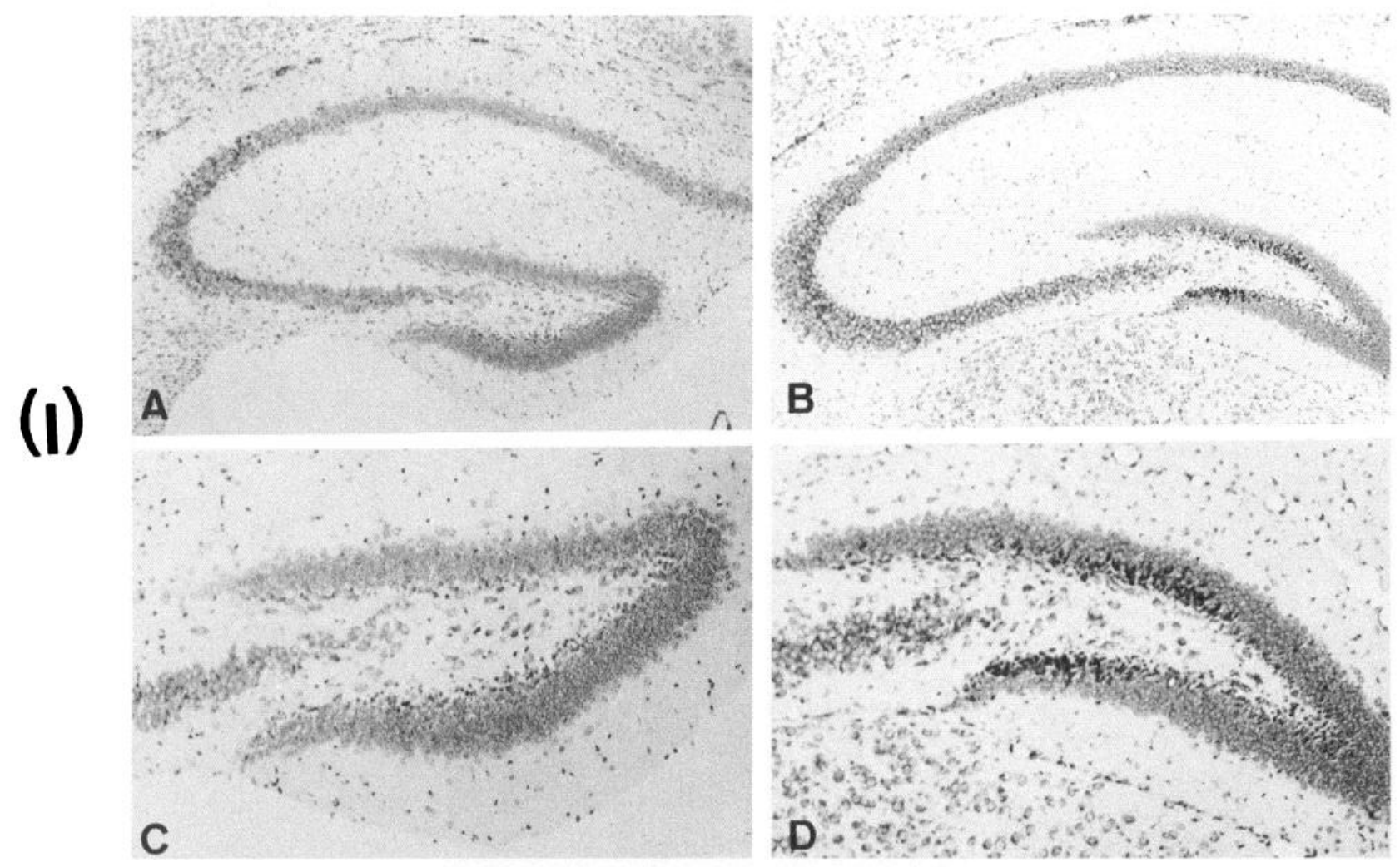

\section{DAYS}
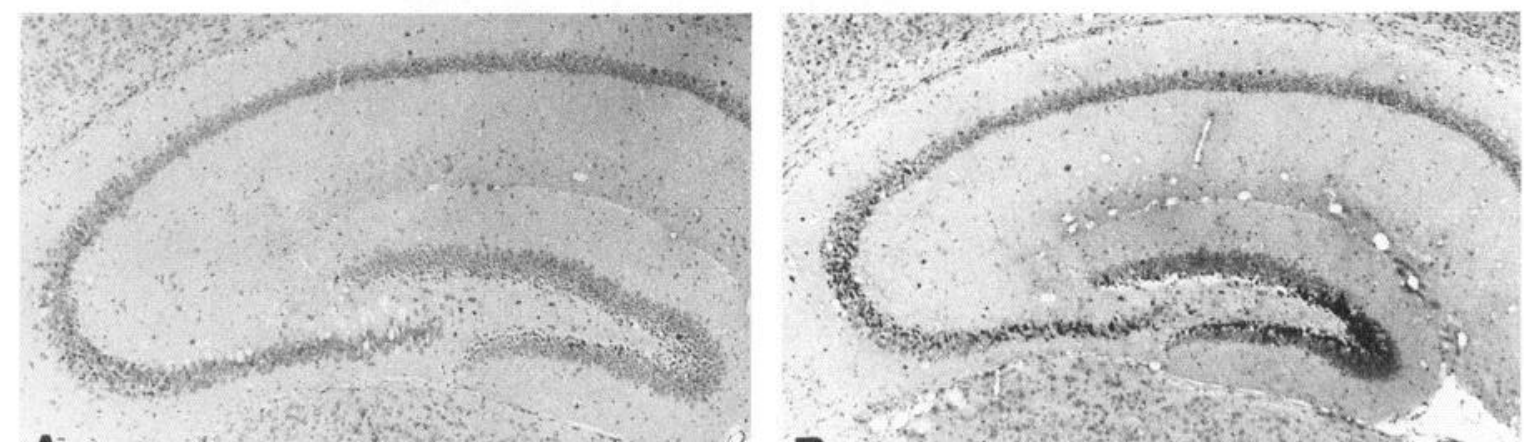

(II)
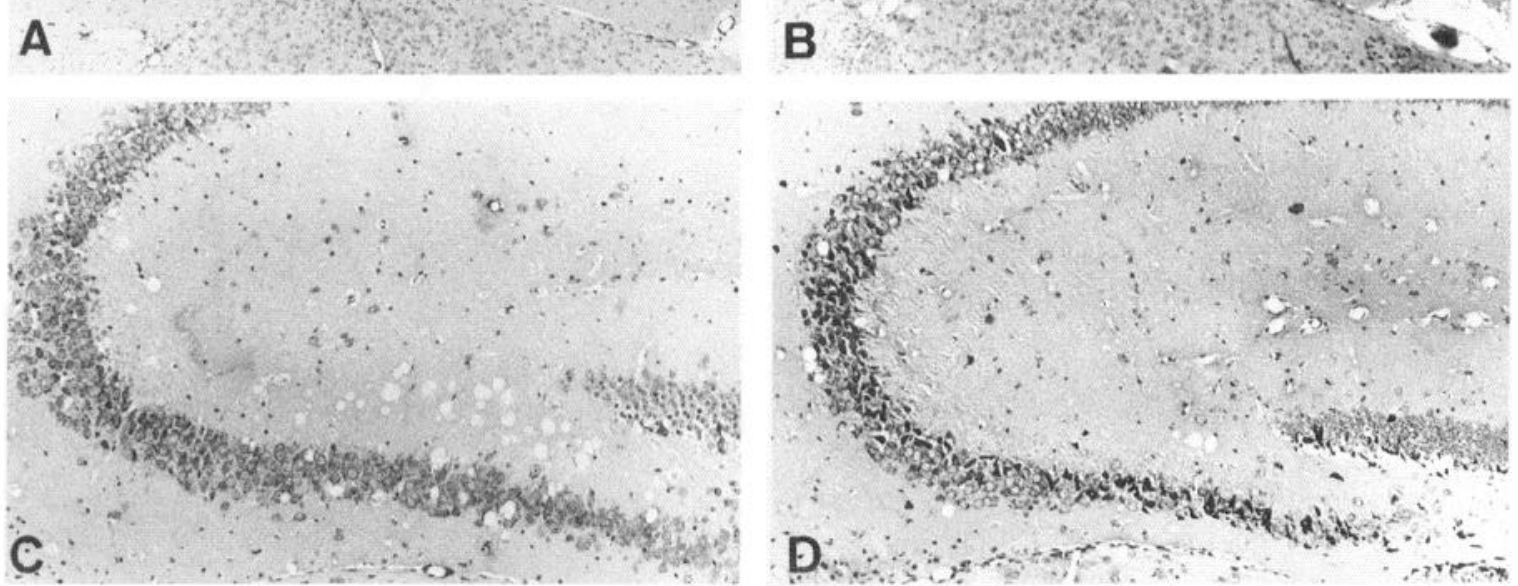
Table 1. 'II-kainate binding to hippocampal synaptosomal membrane fraction from normal and IUD mice at age $30 \mathrm{~d}$

\begin{tabular}{lll} 
& $K_{d}(\mathrm{nM})$ & $B_{\max }(\mathrm{nM})$ \\
\hline Control & $60 \pm 5$ & $1.05 \pm 0.05$ \\
IUD & $63 \pm 6$ & $1.83 \pm 0.07^{*}$
\end{tabular}

Data are mean \pm SEM of eight separate experiments, each assayed in triplicate. *Maximal binding $\left(B_{\max }\right)$ values were significantly $(p<0.01)$ increased in IUD mice.

cells with pyknotic appearance, were observed in CA3 and the dentate gyrus regions [Fig. 7, (I)]. Pyramidal cells did not exhibit any apparent abnormality. At the chronological age of $30 \mathrm{~d}$, neuropathological changes were evident in other hippocampal regions including CA4 as well [Fig. 7, (II)]. In general, granular cells of the dentate gyrus and cells from the CA 3 region exhibited maximum neuronal damage, observed particularly in animals of age $30 \mathrm{~d}$. CA1 and CA2 regions remained preserved.

\section{${ }^{3} H$-kainate receptor binding}

There was a significant increase in the maximal binding $\left(B_{\text {max }}\right)$ of ${ }^{3} \mathrm{H}$-kainate to kainate receptors from the hippocampal synaptosomal membranes, obtained from $30 \mathrm{~d}$ old IUD mice, as compared to controls. There was no significant difference in the binding affinities $\left(K_{d}\right)$ of kainate between the IUD and control mice membrane preparations (Table 1 ).

\section{Brain regional $G A B A$ and glutamate levels}

Brain regional GABA levels were significantly $(p<0.05)$ reduced in IUD mice of age $30 \mathrm{~d}$. Glutamate levels were significantly $(p<0.01)$ increased in the IUD mice (Table 2). A significant increase in glutamate and a reduction in GABA were observed in the cerebral cortex and hippocampus of normal mice $4 \mathrm{hr}$ after domoic acid administration (Table 3 ).

\section{GS activity of cerebral cortex and hippocampus}

GS activity was inhibited by domoic acid in vitro. GS activity was also significantly reduced in the cerebral cortex and hippocampus $4 \mathrm{hr}$ after domoic acid administration to 30-d-old mice. GS activities in cerebral cortex were $348 \pm 8$ and $264 \pm$ $7 \mathrm{nmol} / \mathrm{mg}$ protein $/ \mathrm{hr}$ in the control and domoic acid-treated mice, respectively $(p<0.01)$. Iippocampal GS activities were $323 \pm 5 \mathrm{nmol} / \mathrm{mg}$ protein $/ \mathrm{hr}$ in control and $207 \pm 10 \mathrm{nmol} /$ $\mathrm{mg}$ protein $/ \mathrm{hr}$ in the domoic acid-treated mice $(p<0.01)$.

\section{Calcium influx}

Calcium influx was significantly $(p<0.01)$ increased in cerebral cortex and hippocampal slices $4 \mathrm{hr}$ after domoic acid $(0.6 \mathrm{mg} /$ $\mathrm{kg}$, i.v.) injection to control mice (Table 4). Hippocampal slices obtained from IUD mice of age $30 \mathrm{~d}$ exhibited a significant ( $p$ $<0.05)$ increase in calcium influx as compared to controls ( $\mathrm{Ta}$ ble 5). These results indicate that in both acute experiments and delayed onset experiments in IUD mice, there were increases in the intracellular calcium influx. These changes might follow an increase in the sensitivity to glutamate in both acute and delayed domoic acid toxicity.
Table 2. Effect of in utero domoic acid exposure on brain regional GABA and glutamate levels of progeny

\begin{tabular}{llclll} 
& \multicolumn{2}{l}{ Cerebral cortex } & \multicolumn{2}{l}{ Hippocampus } \\
\cline { 2 - 3 } \cline { 5 - 6 } & GABA & Glutamate & GABA & Glutamate \\
\hline Control & $1.6 \pm 0.02$ & $9.5 \pm 0.10$ & $2.4 \pm 0.03$ & $12.0 \pm 0.1$ \\
IUD & $1.0 \pm 0.03^{*}$ & $13 \pm 0.12^{*}$ & $1.5 \pm 0.05^{*}$ & $16.0 \pm 0.2^{*}$
\end{tabular}

Data are mean \pm SEM ( $\mu \mathrm{mol} / \mathrm{gm}$ wet weight of tissue) for five animals in each group. IUD, Dams were injected with domoic acid $(0.6 \mathrm{mg} / \mathrm{kg}$, i.v.) during 13 th day of gestation. Cerebral cortex and hippocampal GABA and glutamate levels were measured in their progeny at age $30 \mathrm{~d}$. Control, Progeny obtained from dams injected with buffered saline on day 13 of gestation.

${ }^{*} p<0.05$ with respect to control.

\section{Discussion}

The aim of the present study was to assess the neurotoxic effects of domoic acid in developing postnatal mice, born to dams treated with domoic acid during the 13 th day of gestation. Although domoic acid is not known to be a mitotic inhibitor, its effect was studied during the period of maximal cell proliferation, as any adverse effect on neuronal development at this stage would be exaggerated. Differentiation of hippocampal layers occurs postnatally during 10-30 d (Angevine, 1965). Differentiation in any region of the brain is accompanied by development of dendritic arborization, increase in the spines, and synaptic densities. It has been reported that kainic acid produces selective dendrotoxic effects while somatic regions are spared (Ben-Ari, 1985). Kainic acid has been shown to inhibit hippocampal neuronal differentiation (Ben-Ari, 1985). Domoic acid, like kainic acid, can produce dendrotoxic effect, and the somatic region might be spared. Similarly, domoic acid can also induce developmentally regulated neuronal excitotoxicity in the hippocampus, which exhibits marked neuronal and synaptic plasticity (Represa et al., 1990).

Hippocampal neuronal damage following administration of domoic acid (10-300 pmol) to adult rats was described by us (Dakshinamurti et al., 1991). Similar observations of neurotoxicity in adult rat hippocampus have been reported (Iverson et al., 1989; Sutherland et al., 1990; Tryphonas et al., 1990a,b; Strain and Tasker, 1991). Teitelbaum et al. (1990) demonstrated neuronal loss and necrosis predominantly in the hippocampus and amygdala of people who died of domoic acid-contaminated mussel poisoning. The pattern of neuronal damage was similar to that seen in domoic acid- or kainic acid-induced neurotoxicity in mice or rats. We now demonstrate that giving a subconvulsive dose of domoic acid to pregnant mice produces profound impairment in hippocampal functions in their offspring.

Significantly reduced brain regional GABA and increased glutamate levels were observed in the cerebral cortex and hippocampus of IUD mice. GABA levels were also significantly reduced after $4 \mathrm{hr}$ of domoic acid administration in normal 30 d-old mice. Domoic acid treatment also resulted in a significant reduction in the activity of GAD (Dakshinamurti et al., 1991; Sharma and Dakshinamurti, 1992). These observations are similar to those of Ben-Ari (1985) with kainate-mediated brain damage in rats. He has suggested a reduction in GABA-medi-

Figure 7. (I), Thionin-stained coronal section of 14-d-old control mice $(A, 350 \times ; C, 750 \times)$; IUD mouse hippocampus exhibited neuronal damage and dark pyknotic cells in the CA3 and dentate gyrus regions $(B, 350 \times ; D, 650 \times)$. (II), Control $(A, 350 \times ; C, 750 \times)$ and IUD $(B, 350 \times ; D, 750 \times)$ 30-d-old mice. IUD mice show progressive spread of neuronal loss (densely stained dark pyknotic cells) in the CA3, CA4, and dentate gyrus regions. 
Table 3. Brain regional GABA and glutamate levels in domoic acid-treated mice

\begin{tabular}{|c|c|c|c|c|}
\hline & \multicolumn{2}{|c|}{ Cerebral cortex } & \multicolumn{2}{|c|}{ Hippocampus } \\
\hline & GABA & Glutamate & GABA & Glutamate \\
\hline Control & $1.5 \pm 0.06$ & $11.5 \pm 0.12$ & $2.1 \pm 0.04$ & $13.5 \pm 0.1$ \\
\hline Domoic acid treated & $1.0 \pm 0.03^{*}$ & $15.4 \pm 0.15^{*}$ & $1.3 \pm 0.05^{*}$ & $18.0 \pm 0.2^{*}$ \\
\hline
\end{tabular}

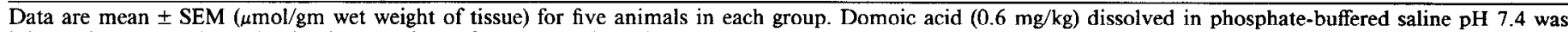
injected intravenously, and animals were killed after $4 \mathrm{hr}$. Brain regional GABA and glutamate levels were determined.

${ }^{*} p<0.01$ with respect to control.

ated cerebral neurotransmission as the basis of seizures in these animals. Domoic acid enhances $\mathrm{KCl}$-induced glutamate release from the rat hippocampal slices (Dakshinamurti et al., 1991). Ferkany and Coyle (1983) have also reported a similar increase in glutamate and aspartate release from rat hippocampal slices pretreated with kainic acid.

Both GAD and GS enzymatic activities were significantly reduced in domoic acid-treated mice. GAD is of neuronal and GS of glial cell origin. GAD is involved in the conversion of glutamate to GABA in the presence of PLP as a coenzyme, whilc GS is involved in the conversion of glutamatc to glutamine. These two enzymes are involved in maintaining homeostasis of GABA and glutamate in the brain (Patel et al., 1982). When GAD is inhibited by toxins such as domoic acid, GABA synthesis is inhibited and seizure, following neuronal excitotoxicity, occurs. Similarly, conversion of glutamate to glutamine by GS is involved in buffering the accumulation of extracellular glutamate, which otherwise will reduce the brain $\mathrm{pH}$. This can lead to excitotoxicity. Persistent excitotoxicity induced by agents like kainic acid has been reported to produce neuronal damage in the hippocampal region (Ben Ari, 1985; Represa et al., 1990). 1990).

We have also observed enhanced kainate receptor binding to the hippocampal synaptosomal membranes prepared from IUD mice. This supports the recent findings of synaptic plasticity in kainic acid-treated rat hippocampus (Tauck and Nadler, 1985; Rcpresa et al., 1989a,b, 1990). Although Savage ct al. (1984) had reported reduced kainate receptor binding in kainic acidtreated rat hippocampus, in more recent work, Represa et al. (1989, 1990) using quantitative autoradiography and Timm staining have shown increased kainate binding in kainate-treated rats. Their study provides evidence for neuronal sprouting and hence synaptic plasticity in the hippocampus. Enhanced kainate receptor binding to hippocampal synaptosomal membranes of IUD mice, observed in the present study, is similar to the observations of Represa et al. (1989a,b, 1990). Domoic acid induces hippocampal pathology by significantly reducing the brain regional GABA and increasing the neuronal glutamate

Table 4. Effect of domoic acid on ${ }^{45} \mathrm{Ca}$ influx into cerebral cortex and hippocampal slices $4 \mathrm{hr}$ after domoic acid treatment

\begin{tabular}{lll} 
& \multicolumn{2}{l}{${ }^{45} \mathrm{Ca}$ Influx $(\mathrm{mmol} / \mathrm{kg} / \mathrm{hr})$} \\
\cline { 2 - 3 } & Cortical slices & $\begin{array}{l}\text { Hippocampal } \\
\text { slices }\end{array}$ \\
\hline Control & $0.13 \pm 0.01$ & $0.14 \pm 0.01$ \\
Domoic acid treated & $0.20 \pm 0.03^{*}$ & $0.25 \pm 0.04^{*}$
\end{tabular}

Data are mean \pm SEM for six separate determinations in each group.

${ }^{*} p<0.05$ with respect to control. release, which may result in calcium-induced cellular damage (Manev et al., 1989). Due to developmental neuroplasticity glutamate (kainate) receptors are increased, which might further increase neurotoxicity in various hippocampal regions that are developmentally regulated (Wozniak et al., 1991).

It is significant that hippocampal neuronal damage in IUD mice was progressive and neuronal death was apparent in the offspring at $30 \mathrm{~d}$ of chronological age. The delayed death of these neurons cannot be attributed to the acute excitotoxicity of domoic acid. These effects could be direct or indirect following alterations in the normal development of the hippocampus and might be attributed to the ongoing increased sensitivity of the cells to endogenous glutamate. This is suggested by our observations of increased kainate receptors, calcium influx, and decreased glutamate metabolic enzymes in these animals.

Domoic acid significantly increased the calcium influx through hippocampal slices. Kainic acid has also been reported to increase intracellular calcium in the cortical cells through glutamate receptor activation (Berdichevsky et al., 1983). Choi (1992) describes the excitotoxic cell death following exposure to glutamate as having two components - the rapidly triggered excitotoxicity induced by brief and intense stimulation of NMDA receptors and the slowly triggered excitotoxicity induced by the prolonged stimulation of AMPA/kainate receptors. He has provided evidence to indicate that the delayed glutamate neurotoxicity is mediated by an abnormal elevation of intracellular calcium. This is supported indirectly by the observations of Sloviter (1989) that neurons containing a high concentration of calcium-binding proteins are relatively resistant to excitotoxic injury. Hippocampal CA3 region seems to be more vulnerable to seizure activity as calbindin concentrations are very low in this region (Baimbridge and Miller, 1984). Apoptosis has been linked to loss of intracellular calcium homeostasis (Nicotera et al., 1989).

The induction of immediate-early genes (IEGs) such as c-fos and $\mathrm{c}-j u n$ is seen within $30 \mathrm{~min}$ following intravenous domoic acid administration (S. K. Sharma, K. Dakshinamurti, J. Peeling, R. J. Buist, and N. Pallay, unpublished observations). These IEGs have been proposed to mediate transcriptional activation

Table 5. In vivo domoic acid-mediated ${ }^{45} \mathrm{Ca}$ influx into cortical and hippocampal slices obtained from control and IUD mice

\begin{tabular}{lll} 
& \multicolumn{2}{c}{${ }^{45} \mathrm{Ca}$ Influx $(\mathrm{mmol} / \mathrm{kg} / \mathrm{hr})$} \\
\cline { 2 - 3 } Control & Cerebral cortex & Hippocampus \\
\hline IUD & $0.12 \pm 0.01$ & $0.15 \pm 0.01$ \\
& $0.19 \pm 0.02^{*}$ & $0.23 \pm 0.03^{*}$ \\
\hline
\end{tabular}

Data are mean \pm SEM for six separate determinations in each group. ${ }^{*} p<0.05$ with respect to control. 
of late-onset genes (Sonnenberg et al., 1989). Although the precise mechanism of the neurotoxicity of domoic acid has not been established in this study, we have demonstrated that a single subconvulsive dose of domoic acid given to pregnant mice produces significant and progressive impairment of hippocampal function and morphology. It is possible that other toxins might have similar prenatal neurotoxicity.

Our findings may have relevance to the pathogenesis of human temporal lobe epilepsy (TLE). Hippocampal neuronal loss is the hallmark of human TLE. Whether this is the result of repeated seizures or the cause of epilepsy is unclear (Engel, 1989). It is currently believed that certain early childhood events such as febrile seizures with resulting excitotoxicity produce hippocampal changes that in turn result in subsequent seizures. Our results, for the first time, provide support for the hypothesis that exposure to excitotoxins early in life may result in progressive hippocampal changes. Longer time observations will be necessary to demonstrate whether the observed hippocampal changes lead to clinical seizures.

\section{References}

Angevine JB Jr (1965) Time of neuron origin in the hippocampus region. An autoradiographic study in the mouse. Exp Neurol [Suppl] 2:1-70.

Baimbridge KG, Miller JJ (1984) Hippocampal calcium-binding protein during commissural kindling-induced epileptogenesis: progressive decline and effects of anticonvulsants. Brain Res 324:85-90.

Ben-Ari Y (1985) Limbic seizures and brain damage produced by kainic acid: mechanisms and relevance to human temporal lobe epilepsy. Neuroscience 14:375-403.

Berdichevsky E, Riveros N, Sanchaz-Armass S, Orrego F (1983) Kainate, $N$-methyl aspartate, and other excitatory amino acid increase calcium influx into rat brain cortex cells in vitro. Neurosci Lett 36: $75-80$.

Bradford MM (1976) A rapid and sensitive method for the quantitation of microgram quantities of protein utilizing the principle of protein-dye binding. Anal Biochem 72:248-254.

Choi DW (1992) Excitotoxic cell death. J Neurobiol 23:1261-1276.

Dakshinamurti K, Stephens MC (1969) Pyridoxine deficiency in the neonatal rat. J Neurochem 16:1515-1522.

Dakshinamurti K, Sharma SK, Sundaram M (1991) Domoic acid induced seizure activity in rats. Neurosci Lett 127:193-197.

Donazati BA, Yamamoto BK (1988) An improved and rapid HPLCEC method for the isocratic separation of amino acid neurotransmitters from brain tissue and microdialysis perfusates. Life Sci 43: 913-922.

Debonnel G, Beauchesne L, deMontigny C (1989) Domoic acid, the alleged "mussel neurotoxin" might produce its neurotoxic effect through kainate receptor activation: an electrophysiological study in rat dorsal hippocampus. Can J Physiol Pharmacol 67:29-33.

Engel J Jr (1989) Causes of human epilepsy. In: Seizures and epilepsy (Engel J Jr, ed), pp 112-134. Philadelphia: Davis.

Ferkany JW, Coyle JT (1983) Kainic acid selectively stimulate the release of endogenous excitatory amino acids. J Pharmacol Exp Ther 225:399-406.

Foster AC, Mena EE, Monaghan DT, Cotman CW (1981) Synaptic localization of kainic acid binding sites. Nature 289:73-75.

Gourmelon P, Briet D, Court L, Tsiang H (1986) Electrophysiological and sleep alterations in experimental mouse rabies. Brain Res 398: 128-140.

Iverson F, Truelove J, Nera E, Tryphonas L, Campbell J, Lok E (1989) Domoic acid poisoning and mussel-associated intoxication: preliminary investigations into the responses of mice and rats to toxic mussel extract. Food Chem Toxicol 27:377-384.
London ED, Coyle JT (1979) Specific binding of $\left[{ }^{3} \mathrm{H}\right] \mathrm{kainic}$ acid to receptor sites in rat brain. Mol Pharmacol 15:492-505.

Manev H, Favaron M, Gudotti A, Costa E (1989) Delayed increase of $\mathrm{Ca}^{2+}$ influx elicited by glutamate: role in neuronal death. $\mathrm{Mol}$ Pharmacol 36:106-112.

Nicotera P, McConkey DJ, Dijplukt JM, Jones DP, Orrenius S (1989) $\mathrm{Ca}^{2+}$-activated mechanism in cell killing. Drug Metab Rev 20:193201.

Patel AJ, Hunt A, Fordon RD, Balazs R (1982) The activities in different neural cell types of certain enzymes associated with the metabolic compartmentation of glutamate. Dev Brain Res 4:3-11.

Pishak MR, Phillips AT (1979) A modified radioisotopic assay for measuring glutamine synthetase activity in tissue extracts. Anal Biochem 94:82-92.

Represa A, Le Gall La Sall G, Ben-Ari Y (1989a) Hippocampal plasticity in the kindling model of epilepsy in rats. Neurosci Lett 99:345350.

Represa A, Robin O, Tremblay E, Ben-Ari Y (1989b) Hippocampal plasticity in childhood epilepsy. Neurosci Lett 99:351-355.

Represa A, Tremblay E, Ben-Ari Y (1990) Sprouting of mossy fibers in the hippocampus of epileptic human and rat. In: Excitatory amino acids and neuronal plasticity (Ben-Ari Y, ed), pp 419-424. New York: Plenum.

Savage D, Nadler JV, McNamara JO (1984) Reduced kainic acid binding in rat hippocampal formation after limbic kindling. Brain Res 323:128-131.

Scatchard T (1949) The attraction of proteins for small molecules and ions. Ann NY Acad Sci 51:660-672.

Schwob JE, Fuller T, Price JL, Olney JW (1980) Wide spread patterns of neuronal damage following systemic or intracerebral injections of kainic acid: a histological study. Neuroscience 5:991-1014.

Sharma SK, Dakshinamurti K (1992) Seizure activity in pyridoxinedeficient adult rats. Epilepsia 33:235-247.

Sloviter RS (1989) Calcium-binding proteins (calbindin-D28K) and parvalbumin immunocytochemistry: localization in the rat hippocampus with specific reference to the selective vulnerability of hippocampal neurons in situ. J Comp Neurol 280:183-196.

Sonnenberg JL, Rausccher FJ, Morgan JI, Curran T (1989) Regulation of proenkephalin by Fos and Jun. Science 246:1622-1625.

Stewart GR, Zorumski CF, Price MT, Olney JW (1990) Domoic acid: a dementia-inducing excitotoxic food poison with kainic acid receptor specificity. Exp Neurol 110:127-138.

Strain SM, Tasker RAR (1991) Hippocampal damage produced by systemic injections of domoic acid in mice. Neuroscience 44:343352.

Sutherland RJ, Hoesing JM, Whishaw IQ (1990) Domoic acid, an environmental toxin, produces hippocampal damage and severe memory impairment. Neurosci Lett 120:221-223.

Tauck DL, Nadler JV (1985) Evidence for functional mossy fiber sprouting in hippocampal formation of kainic acid treated rats. $J$ Neurosci 5:1016-1022.

Teitelbaum JS, Zatorrem RJ, Carpenter S, Gendron D, Evans AC, Gjdde A, Cashman NR (1990) Neurologic sequelae of domoic acid intoxication due to the ingestion of contaminated mussels. N Engl J Med 322:1781-1787.

Tryphonas L, Truelove J, Nera E, Iverson F (1990a) Acute neurotoxicity of domoic acid in the rat. Toxicol Pathol 18:1-9.

Tryphonas L, Truelove J, Todd E, Nera E, Iverson F (1990b) Experimental oral toxicity of domoic acid in cynomolgus monkeys (Macaca fascicularis) and rats. Preliminary investigations. Food Chem Toxicol 28:707-715.

Viswanathan M, Bose R, Dakshinamurti K (1991) Increased calcium influx in caudal artery of rats made hypertensive with pyridoxine deficiency. Am J Hypertens 4:253-255.

Whishaw IQ, Cioc JD, Previsich N, Kolb B (1977) The variability of the interaural line vs the stability of bregma in rat stereotaxic surgery. Physiol Behav 19:719-722.

Wozniak DF, Stewart GR, Miller JP, Olney JW (1991) Age-related sensitivity to kainate neurotoxicity. Exp Neurol 114:250-253. 